\title{
Candy crush: a confounding presentation of blood per rectum in a child
}

\author{
Yvonne Ying Ru Ng, Han Lim Ong, Siam Wee Sim, Caroline Choo Phaik Ong
}

Department of Paediatric Surgery, KK Women's and Children's Hospital, Singapore, Singapore

\section{Correspondence to} Dr Yvonne Ying Ru Ng, yvonne.ng@mohh.com.sg

Accepted 28 July 2015
CrossMark

To cite: $\mathrm{Ng}$ YYR, Ong HL, Sim SW, et al. BMJ Case Rep Published online: [please include Day Month Year] doi:10.1136/bcr-2015211634

\section{DESCRIPTION}

Acute per rectal bleeding in a young child is a fairly common clinical presentation that warrants immediate attention and appropriate management. ${ }^{1}$ Aetiology differs with age and differential diagnosis in a young child includes: intussusception, bleeding Meckel's diverticulum, dysentery, juvenile polyps, inflammatory bowel disease and vascular lesions. ${ }^{2}$

A 3-year-old boy presented to the emergency department with a 1-day history of painless rectal bleeding not associated with fever or diarrhoea. Physical examination revealed bright red stools on digital rectal examination (figure 1), but there was otherwise no abdominal tenderness or mass elicited. Blood tests showed normal haemoglobin, white cell count and $\mathrm{C}$ reactive protein levels. Faecal occult blood test was negative. Sonographic study of the abdomen was normal.

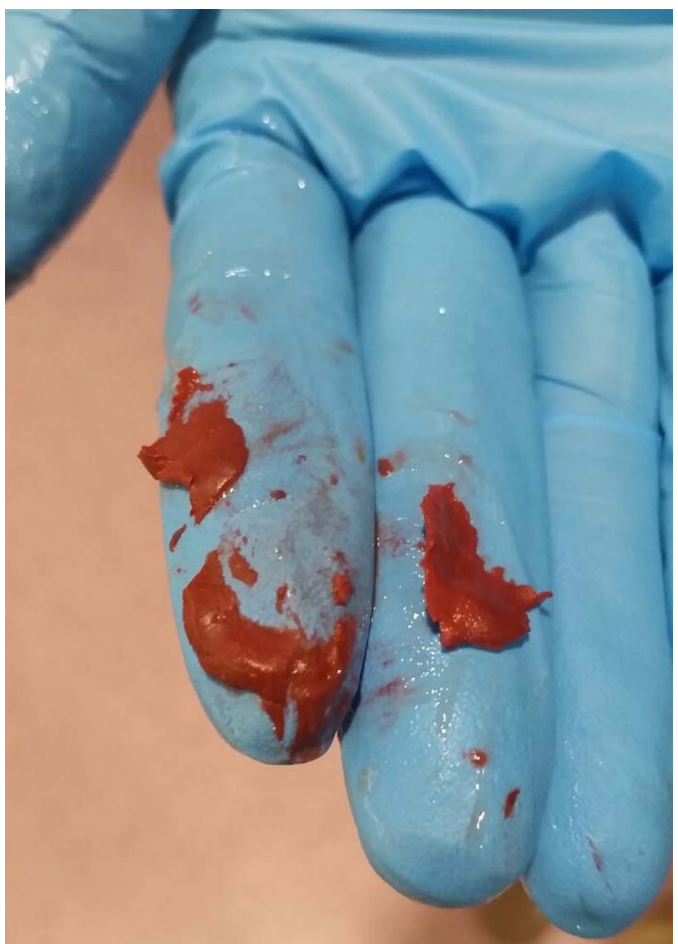

Figure 1 Bright red stools found on per rectal examination.
On repeat probing, the child admitted to consuming large amounts (about $150 \mathrm{~g}$ ) of pink and purple coloured chewy candy containing gum arabic. The presence of undigested sugars was confirmed by positive stool test for reducing substance. Unexpectedly, the consumption of pink and purple candy had resulted in a red coloured gum that mimicked the presentation of blood in the stools of our patient. Recognition of such unusual digested substances as a differential for per rectal bleeding will avoid unnecessary investigations and hospital admission.

\section{Learning points}

Acute per rectum bleeding in a young child is often benign but potentially dangerous. Conditions such as intussusception, bleeding Meckel's diverticulum and inflammatory bowel disease must be excluded.

- Undigested coloured gum can mimic a presentation of blood in stools. Being cognisant of it can avoid excessive management.

Acknowledgements The authors would like to acknowledge Dr Maria Remedios A Lipa for her photograph contribution to this report.

Contributors YYRN contributed to the conception and design and acquisition and analysis of the data. She was involved in drafting the manuscript. HLO contributed to the acquisition and analysis of the data. SWS and CCPO were involved in conception and design, and drafting the manuscript and revising it critically for important intellectual content. They also gave final approval of the version to be published. All the authors read and approved the final manuscript.

Competing interests None declared.

Patient consent Obtained.

Provenance and peer review Not commissioned; externally peer reviewed.

\section{REFERENCES}

1 Balachandran B, Singhi S. Emergency management of lower gastrointestinal bleed in children. Indian J Pediatr 2013;80:219-25.

2 Teach SJ, Fleisher GR. Rectal bleeding in the pediatric emergency department. Ann Emerg Med 1994;23:1252-8. 
Copyright 2015 BMJ Publishing Group. All rights reserved. For permission to reuse any of this content visit http://group.bmj.com/group/rights-licensing/permissions.

BMJ Case Report Fellows may re-use this article for personal use and teaching without any further permission.

Become a Fellow of BMJ Case Reports today and you can:

- Submit as many cases as you like

- Enjoy fast sympathetic peer review and rapid publication of accepted articles

- Access all the published articles

- Re-use any of the published material for personal use and teaching without further permission

For information on Institutional Fellowships contact consortiasales@bmjgroup.com

Visit casereports.bmj.com for more articles like this and to become a Fellow 